 \\ z Filologii Polskiej i Słowiańskiej
}

\author{
Paweł Kowalski \\ (Instytut Slawistyki PAN, Warszawa)
}

\section{Abstrakt i adnotacja jako element opisu dokumentu w bazie iSybislaw}

W dobie szeroko zakrojonej i dynamicznej cyfryzacji, której podlega współczesna nauka, systemy informacyjno-wyszukiwawcze (w tym bazy bibliograficzne) jako narzędzie usprawniające proces naukowy i ułatwiające pracę naukową pełnią coraz ważniejszą rolę. Opisy bibliograficzne zawarte w bazach bibliograficznych, będące określeniem konkretnego dokumentu, charakteryzują się różnym stopniem szczegółowości. W opisie podstawowym wymienia się przede wszystkim dane pracy zaczerpnięte z jej strony tytułowej, takie jak m.in. autor, tytuł, rok i miejsce wydania. Opis bibliograficzny może być jednak poszerzony o krótki tekst dotyczący treści publikacji, nazywany w dalszej części artykułu abstraktem.

Teksty takie są przedmiotem niniejszego artykułu. Stanowią one jeden z elementów opisu bibliograficznego w systemie informacyjnym iSybislaw, dostępnym pod adresem http://www.isybislaw.ispan.waw.pl. iSybislaw jest systemem informacji dokumentacyjnej językoznawstwa slawistycznego, w którym znajdują się opisy bibliograficzne prac slawistycznych z całego świata. Omawiane w pracy abstrakty zamieszczane są w dwóch polach struktury

This is an Open Access article distributed under the terms of the Creative Commons Attribution 3.0 PL License (creativecommons.org/licenses/by/3.0/pl/), which permits redistribution, commercial and non-commercial, provided that the article is properly cited. (c) The Author(s) 2014.

Publisher: Institute of Slavic Studies, PAS \& The Slavic Foundation

[Wydawca: Instytut Slawistyki PAN \& Fundacja Slawistyczna] 
systemu: Abstrakt i Abstrakt 2. W literaturze przedmiotu można spotkać różne terminy dotyczące krótkich form tekstowych, które uzupełniają opisy bibliograficzne. Mogą to być adnotacje lub abstrakty (analizy dokumentacyjne), niekiedy używany jest również termin streszczenie.

Dość często terminy streszczenie i abstrakt są stosowane zamiennie. Także w różnych formularzach konferencyjnych można zauważyć ich wymienne używanie. Zasadne wydaje się jednak rozróżnianie tych dwóch form tekstowych. Różnice pomiędzy abstraktem a streszczeniem są widoczne między innymi podczas lektury czasopism naukowych. Abstrakt to tekst krótki, wprowadzający w treść artykułu lub innej pracy, znajdujący się najczęściej poniżej tytułu i przed tekstem głównym. Streszczenie natomiast znajduje się na końcu pracy. Jest obszerniejsze, zawiera więcej informacji. Przykład może stanowić słoweńskie czasopismo „Slavia Centralis”, publikowane w wolnym dostępie w internecie, gdzie autorzy zamieszczają na początku artykułów abstrakty w języku słoweńskim i angielskim wraz ze słowami kluczowymi w obu językach, natomiast na końcu podają obszerne streszczenie $\mathrm{w}$ formie omówienia pracy. Także w środowisku polskim daje się zauważyć tendencję do zamieszczania abstraktów przed artykułami, np. w czasopiśmie „Cognitive Studies” publikowane są abstrakty artykułów w języku angielskim, podobnie w czasopiśmie „Studia Anglica Posnaniensia” abstrakty w języku angielskim znajdują się przed tekstami poszczególnych artykułów.

W niniejszej pracy znajdą się definicje powyższych terminów wraz z ich elementami konstytutywnymi, omówiona zostanie także charakterystyka tekstów zamieszczanych w polach: Abstrakt i Abstrakt $2 \mathrm{w}$ bazie iSybislaw, ich możliwości informacyjne oraz miejsce w opisie bibliograficznym. Na podstawie przykładów zaczerpniętych z systemu iSybislaw zaproponowana zostanie ich typologia.

Zakres podejmowanych $\mathrm{w}$ artykule zagadnień wchodzi w obszar zainteresowań bibliologii, informacji naukowej oraz szeroko pojmowanej lingwistyki tekstu. Opracowywane w bazie iSybislaw dokumenty to prace slawistyczne i językoznawcze. Charakteryzują się więc specyficzną terminologią, co sytuuje je jako przedmiot badań lingwistyki tekstu specjalistycznego, dziedziny młodej, wyrosłej z zainteresowań terminologicznych (Grucza, 2004).

Omawiane krótkie formy pisemne jako element opisu bibliograficznego w systemie iSybislaw wyrażane są w języku naturalnym, w przeciwieństwie do innych elementów takiego opisu, jak np. słowa kluczowe. Autorami tekstów są osoby opracowujące poszczególne dokumenty. Jest to więc podejście odmienne 
od spotykanych w innych bazach danych, gdzie najczęściej wykorzystuje się streszczenia dołączane przez autora pracy (artykułu, monografii). Abstrakty powstają zazwyczaj w języku dokumentu. W bazie iSybislaw występują teksty pisane we wszystkich językach słowiańskich, a także w innych językach naturalnych. Zamieszczane są one w polu Abstrakt. W polu Abstrakt 2 podaje się tłumaczenia na język polski tekstów zawartych w polu Abstrakt.

W różnych pracach można spotkać mniej lub bardziej rozbudowane definicje terminów: adnotacja, abstrakt, streszczenie. W Słowniku języka polskiego PWN można przeczytać, że adnotacja to dopisek, czyli notatka dodana do tekstu (Drabik, Kubiak-Sokół, Sobol \& Wiśniakowska, 2010, ss. 3, 51). Streszczenie w tym słowniku definiowane jest między innymi jako „treść czegoś ujęta krótko, zwięźle" (Drabik i in., 2010, s. 966). Bardziej rozbudowaną definicję streszczenia przytoczono w Słowniku encyklopedycznym informacji, języków i systemów informacyjno-wyszukiwawczych. Według niej streszczenie to tekst będący wynikiem streszczania, czyli transformacji tekstu polegającej na selekcjonowaniu informacji, której wynikiem jest tekst krótszy od tekstu wejściowego, zawierający najważniejsze informacje transformowanego tekstu (Bojar, 2002, ss. 249-250). Wyróżniono dwa typy streszczeń: autorskie i dokumentacyjne. Streszczenie autorskie, w słowniku nazywane także abstraktem autorskim lub synopsisem, sporządzane jest przez autora tekstu. Natomiast streszczenie dokumentacyjne, nazywane także analiza dokumentacyjna, wszechstronnie odwzorowuje treść dokumentu, a jako kondensat treści może w pewnych sytuacjach zastąpić streszczany dokument (Bojar, 2002, s. 250). Najczęściej takie streszczenia mają dużą objętość i zamieszczane są na końcu dokumentów.

Adnotację scharakteryzowano jako „metainformację o treści i/ lub cechach formalnych dokumentów najczęściej będącą tekstem w języku naturalnym towarzyszącą opisowi bibliograficznemu lub bezpośrednio dokumentowi" (Bojar, 2002, s. 15). Wyróżniono następujące typy adnotacji:

- adnotacja wyjaśniająca, zawierająca wyjaśnienie niejasnego tytułu dokumentu lub tytułu o przenośnym znaczeniu, czasem uzupełniająca informacje zawarte w tytule lub je precyzująca. Składa się z kilku zdań, które dookreślają treść dokumentu (Bojar, 2002, s. 15);

- zawartościowa, w pełni lub częściowo odwzorowująca spis treści dokumentu (wyliczająca zawarte w nim utwory lub części składowe). Najczęściej stosowana w przypadku dokumentów o rozbudowanej strukturze oraz prac zbiorowych (Bojar, 2002, s. 16); 
- księgoznawcza, zawierająca informacje o cechach formalnych dokumentu i ewentualnie innych cechach relewantnych dla użytkownika informacji, np. takich jak cechy fizyczne (rodzaj druku, papieru, oprawy, ilustracje itp.), przeznaczenie czytelnicze (określenie użytkownika, dla którego dokument przeznaczono), związki bibliograficzne $\mathrm{z}$ innymi dokumentami (np. recenzje, polemiki) (Bojar, 2002, s. 15);

- zalecająca, która może łączyć cechy adnotacji treściowej i adnotacji księgoznawczej, zawierająca m.in. informacje o poziomie opracowania przedmiotu dokumentu, czyli tematu, i wskazująca użytkownika informacji, dla którego dokument przeznaczono (tzw. przeznaczenie czytelnicze), zachęcająca do czytania dokumentu oraz uzasadniająca jego wartość (Bojar, 2002, ss. 15-16);

- czasem też wyróżniana treściowa, będąca typem adnotacji łączącej cechy adnotacji wyjaśniającej i zawartościowej (zob. Bojar, 2002, s. 15).

Tekstem stanowiącym jeden z elementów opisu bibliograficznego, jednak różniącym się od adnotacji, jest abstrakt. W literaturze polskiej termin preferowany to analiza dokumentacyjna. W Słowniku encyklopedycznym informacji, języków i systemów informacyjno-wyszukiwawczych w definicji analizy dokumentacyjnej można przeczytać, że jest to

„metainformacja o treści dokumentu będąca tekstem w języku naturalnym, stanowiąca streszczenie dokumentu dokonane zgodnie z kryteriami przyjętymi $\mathrm{w}$ danym systemie informacyjno-wyszukiwawczym, towarzyszące opisowi bibliograficznemu lub bezpośrednio dokumentowi. Analizy dokumentacyjne sporządza się wówczas, gdy zachodzi potrzeba poinformowania użytkowników informacji o treści i charakterze dokumentu w zakresie szerszym niż czyni to opis bibliograficzny czy charakterystyka wyszukiwawcza dokumentu" (Bojar, 2002, s. 20).

Autorzy wymieniają kilka rodzajów analiz dokumentacyjnych:

- analiza dokumentacyjna omawiająca, która odwzorowuje ważne dla użytkownika informacji cechy relewantne treści dokumentu, takie jak np. główne tezy, podstawowe informacje o przedmiocie i celu, zastosowane metody i uzyskane wyniki, najważniejsze wnioski wraz z ich uzasadnieniem (Bojar, 2002, s. 21);

- analiza dokumentacyjna wskazująca, która odwzorowuje temat (tematy) dokumentu i/lub główne tezy autora. Ma ona na celu powiadomienie użytkownika informacji o istnieniu dokumentu na dany temat a nie odwzorowywanie jego treści (Bojar, 2002, s. 22). 
Wydaje się, że istotną różnicą między streszczeniem a abstraktem w świetle obecnie powstających dokumentów jest przede wszystkim objętość tych dwóch tekstów ${ }^{1}$. Abstrakt stanowi zazwyczaj tekst bardziej zwięzły. Jeszcze raz należy jednak podkreślić, że z jednej strony daje się zauważyć tendencję do rozróżniania terminów abstrakt i streszczenie, zwłaszcza w praktyce wydawniczej, z drugiej zaś oba terminy nadal stosowane są zamiennie, choć najczęściej w komunikacji potocznej.

Podczas prac w ramach projektu Repozytorium Cyfrowe Instytutów Naukowych trwały dyskusje nad kształtem i formą abstraktów zamieszczanych w systemie iSybislaw. Kierując się wytycznymi, które zawarte są w różnych normach dotyczących tworzenia abstraktów i streszczeń2 ${ }^{2}$, przyjęto, że abstrakt w bazie iSybislaw powinien liczyć nie mniej niż trzy zdania, w których przedstawione zostaną cele pracy, metoda (metodologia) i wnioski zawarte w dokumencie. Adnotacja zaś może stanowić tekst krótszy. Kolejnym założeniem było to, że opisy bibliograficzne prac napisanych w języku innym niż polski, niemające streszczenia polskiego $\mathrm{w}$ dokumencie, powinny być uzupełniane o polskie tłumaczenie.

Adnotacje i abstrakty zamieszczone w opisach bibliograficznych pozwalają użytkownikowi wyszukiwać informacje przez wpisanie w polu Szukaj wyrazów zawartych w polach Abstrakt i Abstrakt 2. Istotne jest więc podawanie $\mathrm{w}$ abstraktach i adnotacjach ważnych terminów zawartych w artykule - ułatwia to użytkownikowi wyszukanie pożądanej informacji. W bazie iSybislaw dostępne są dwa rodzaje wyszukiwania: proste i złożone. W obu przypadkach można wyszukiwać według zbiorów słów z pól Abstrakt i Abstrakt 2. W celu zwiększenia efektywności wyszukiwania zalecane jest maskowanie wyrażenia wyszukiwawczego przez użycie znaku ,”" oraz łączenie tych wyrażeń we frazy za pomocą operatorów logicznych, takich jak: AND, OR i NOT.

1 Przyjmując kryteria autorów Słownika encyklopedycznego informacji, języków i systemów informacyjno-wyszukiwawczych można także, bardzo szeroko, traktować streszczenie jako termin nadrzędny (ogólny) w stosunku do omawianych w artykule, bardziej szczegółowych terminów: abstrakt i adnotacja.

${ }^{2}$ Warto tutaj porównać obowiązujące normy międzynarodowe ISO (http://englishforlibrarians.wikispaces.com/file/view/ISO_214_1976_E.pdf), a także wytyczne Europejskiego Stowarzyszenia Redaktorów Naukowych (EASE) dla autorów i tłumaczy artykułów naukowych publikowanych w języku angielskim (http://dobn.pg.gda.pl/files/Artyku\%C5\%82y-naukowe-publikowane-w-j.-angielskim1.pdf). 
System iSybislaw udostępnia obecnie około dwudziestu tysięcy opisów bibliograficznych. Nie wszystkie uzupełniane są adnotacjami lub abstraktami. Na potrzeby tego artykułu wyekscerpowano i poddano analizie 300 rekordów, które zawierają abstrakty. Za kryterium podziału krótkich tekstów zamieszczanych w polu Abstrakt i Abstrakt 2 przyjęto przedstawione powyżej definicje. Pozwoliło to wyróżnić w bazie iSybislaw następujące typy tekstów:

- adnotacje wyjaśniające i zawartościowe;

- abstrakty omawiające (podstawowe i rozbudowane);

- noty (adnotacje) biograficzne.

Poniżej zaprezentowane zostaną ich egzemplifikacje $e^{3}$ :

Adnotacje wyjaśniające:

1. Краков, 27.08-2.09.1998.

2. Zprávao konferenci „Etymologické symposion Brno 1999”. Brno, 7.-9.1999.

3. Konferencja naukowa. Organizatorzy: Zakład Współczesnego Języka Polskiego Uniwersytetu Gdańskiego, Zarząd Główny Towarzystwa Miłośników Języka Polskiego i Wyższe Seminarium Duchowne w Pelplinie.

Adnotacje zawartościowe:

4. Wstęp autorski zawiera rozdziały: 1. Komentarze do słownika (s. VII-XXV). 2. O początkach języka państwowego Polaków i dialektów starosłowiańskich (s. XXV-XXXIX). 3. Skąd się wzięła etymologia i dokąd zmierza (s. XL-XLVII). 4. Autorecenzja słownika krytyczna (s. XLVIII).

5. Spis wszystkich prac A. Zaręby opublikowanych w latach 1947-1991. Bibliografia obejmuje publikacje językoznawcze (w tym przedruki), artykuły o tematyce kulturalno-literackiej i etnograficznej oraz recenzje prac badacza.

6. Badaniem zostały objęte pytania o rozstrzygnięcie, pytania niepełne (kontekstowe) i alternatywne oraz wypowiedzenia o cechach formalnych charakterystycznych dla pytań o rozstrzygnięcie. Uwzględniono również zdania ze ścisłymi synonimami pytać / numaм.

${ }^{3}$ Wszystkie przykłady zaczerpnięte zostały z bibliograficznej bazy danych językoznawstwa slawistycznego iSybislaw (Bibliograficzna baza danych światowego językoznawstwa slawistycznego iSybislaw, b.d.; http://www.isybislaw.ispan.waw.pl). 
7. Artykuł składa się z dwóch części. W pierwszej przedstawiono powojenny stan badań nad idiostylem (stylem pisarza), w drugiej zaś dokonano uogólnień metodologicznych, pośród których ważne miejsce zajmuje m.in. zastosowanie metod ilościowych w badaniach stylistycznych.

Abstrakty omawiające:

8. L'étude s'inspire de la théorie et de la pratique de la traduction et représente un groupe des recherches franco-bulgare, contrastives et cognitives à la fois. On a pour but de formuler des règles d'exploration contextuelle qui feront partie d'un système expert, utilisant et innovante sur le plan de la didactique des langues et de l'enseignement de la traduction. On analyse les textes bulgares tirés des originaux bulgares et les textes en bulgares, traduits des textes français, tirés des originaux français. On examine des significations spécifiques des formes de l'aoriste perfectif, des types d'événements exprimés par les formes de l'aoriste en bulgare, l'ordre des formes de l'aoriste et des événements. L'auteur utilise la terminologie et la méthode reposant sur la théorie de Z. Guentchéva et J. P. Desclés.

9. Celem pracy jest zbadanie, w jaki sposób układały się nazewnicze stosunki polsko-niemieckie na przełomie XII i XIII w. na Śląsku. W przekonaniu historyków niemieckich przełomową datą jest rok 1175, w którym książę Bolesław Wysoki wydał przywilej pozwalający na osadnictwo kolonistów niemieckich. Na podstawie badanego materiału antroponimicznego autor podejmuje próbę ustalenia etniczności osadników. Analizując przywilej fundacyjny Henryka Brodatego dla cysterek w Trzebnicy (1204 r.), udowadnia, że zarówno w warstwie patronimików, jak też imion mamy do czynienia z przygniatającą przewagą nazw polskich, zaś w okresie między 1175 i 1204 nie przybył ani jeden osadnik niemiecki. Autor podkreśla, że choć w innych lokacjach osadnicy niemieccy zaczęli pojawiać się na początku XIII w., to jednak analiza mian z XIII i XIV w. potwierdza, że jeszcze długo na Śląsku utrzymywała się polska antroponimia. Stanowi to dodatkowy argument świadczący o polskości Śląska.

10. Celem artykułu jest porównanie leksyki pochodzącej z pięciu ordynacji, wydrukowanych w polskim przekładzie w latach 1765-1787, ze stanem polszczyzny XIX i XX w. Słownictwo ujęte w dokumentach jest zbliżone do potocznego. Omówiono formy, które nie utrzymały się w systemie leksykalnym: konstrukcje analityczne (rzeczownikowo-przymiotnikowe, 
przysłówkowe i czasownikowe), syntetyczne formy adwerbialne oraz czasowniki prefiksalne. Analiza obejmuje również proces zmian zakresu znaczeniowego czasowników oraz łączliwość leksykalną. Stwierdzono, że na przełomie XIX i XX w. rozpoczęły się zmiany systemu leksykalnego związane z dyferencjacją semantyczną wyrazów o zbliżonych zakresach oraz specjalizacją znaczeniową formantów słowotwórczych.

Noty biograficzne:

11. Wspomnienie o K. Dejnie, znawcy dialektów polskich i słowiańskich, twórcy koncepcji Atlasu gwar polskich. Badacz wprowadził do dialektologii metody fonologiczne oraz stosował metody kartograficzne w opisie zasięgów i zróżnicowań językowych. Przedmiotem zainteresowania K. Dejny były również kontakty językowe na obszarach pogranicznych. W artykule wymieniono prace z zakresu dialektologii polskiej, dialektologii ukraińskiej oraz dydaktyki (nauczania dialektologii).

12. V spomin češkemu jezikoslovcu, bohemistu in slavistu, ki je delal na Filozofski fakulteti Karlove univerze v Pragi. V svojih številnih delih je A. Jedlička obravnaval teme iz področja knjižnega jezika in stilistike, jezikovne kulture, družbenostnega jezikoslovja ter slovaroslovja in slovaropisja.

13. Wspomnienie o białoruskim językoznawcy, badaczu frazeologii, folkloru oraz etnografii języka białoruskiego. Jego praca naukowa zaowocowała dwiema monografiami poświęconymi leksyce przysłów ludowych oraz frazeologii. Aksamitow jest współautorem kilku słowników frazeologicznych, w tym Słownika frazeologicznego białorusko-polskiego (Warszawa, 2000), a także autorem słownika przysłów i porzekadeł białoruskich.

Wymienione przykłady wskazują na bogate środki tekstotwórcze, którymi dysponuje osoba opracowująca opis bibliograficzny. Dokonawszy krótkiej charakterystyki materiału, należy stwierdzić, że adnotacje w bazie iSybislaw to zazwyczaj jedno- lub dwuzdaniowe teksty, zawierające podstawowe dane dotyczące publikacji. W adnotacjach najczęściej pojawiają się daty, nazwy i miejsca konferencji, a także krótka charakterystyka treściowa dokumentu (przykłady 1-7).

Abstrakty zamieszczane w bazie iSybislaw są tekstami dłuższymi. Zawierają takie elementy, jak cel, metoda, niekiedy także opis badanego materiału i wnioski pracy. Przekazują użytkownikowi więcej informacji na temat dokumentu 
niż adnotacje, wymagają więc od osoby je przygotowującej większego nakładu pracy (przykłady 8-10).

W bazie iSybislaw pojawiają się także noty (adnotacje) biograficzne, które dotyczą slawistów językoznawców. To teksty objętością zbliżone do adnotacji. Najczęściej przekazywane są w nich informacje na temat zainteresowań badawczych osoby, której poświęcony jest dokument, dorobku naukowego tej osoby, jej najważniejszych prac, projektów i pełnionych funkcji (przykłady 11-13).

Podsumowując przedstawione powyżej rozważania, można wymienić korzyści płynące z zamieszczania adnotacji i abstraktów w bazie iSybislaw, a także w innych bazach czy systemach informacyjno-wyszukiwawczych. Przede wszystkim teksty takie spełniają niezwykle ważną w procesie wyszukiwawczym funkcję informacyjną. Zamieszczanie krótkich tekstów pozwala użytkownikowi zapoznać się z podstawowymi informacjami faktograficznymi dotyczącymi treści dokumentu. Teksty te dostarczają informacji o celach pracy, metodologii i wnioskach. Pozwalają więc na zapoznanie się z bardziej szczegółowymi informacjami w porównaniu do informacji dostarczanych przez inne narzędzia wyszukiwawcze w bazie, jak słowa kluczowe lub klasyfikacja. Dzięki zamieszczaniu abstraktów i adnotacji użytkownik bazy ma do dyspozycji jeszcze jedno narzędzie, za pomocą którego może dotrzeć do dokumentów najbardziej przydatnych w jego pracy naukowej. Tym samym uwzględnianie tego typu tekstów w opisie bibliograficznym usprawnia pracę naukową i badawczą.

Podawanie adnotacji i abstraktów w opisach bibliograficznych w systemie iSybislaw niesie ze sobą także pewne zagrożenia. Przede wszystkim podczas przetwarzania informacji w procesie opracowania rzeczowego moga się pojawić zagrożenia jakości tego procesu (por. Woźniak, 2002). Dlatego też opracowywane opisy bibliograficzne wraz z adnotacjami, abstraktami i notami bibliograficznymi w systemie iSybislaw przygotowywane są przez specjalistów językoznawców $\mathrm{z}$ różnych państw, którzy posługują się różnymi językami słowiańskimi. Każdy opis bibliograficzny i każdy tekst dołączany do opisu rzeczowego jest weryfikowany w kilkuetapowym procesie. Za formalną stronę odpowiada Zenon Mikos, natomiast nad redakcją merytoryczną czuwa Zofia Rudnik-Karwatowa. Każdy tekst w opisie bibliograficznym jest opatrzony sygnaturą osoby, która go opracowywała. W ten sposób użytkownik może dowiedzieć się, kto przygotował dany opis.

Na zakończenie należy podkreślić, że funkcją omawianych tekstów jest zainteresowanie użytkownika systemu treścią dokumentu. Teksty takie nie 
pretendują do zastępowania oryginalnych dokumentów, jedynie mają na celu wskazanie informacji, które użytkownik może znaleźć w pracy. Jako jeden z elementów opisu bibliograficznego, obok takich pól systemu, jak osoby, tytuły dokumentów, słowa kluczowe i klasyfikacja, stanowią nieocenione źródło informacji o dokumencie. Jeśli posłużyć się metaforą, można cały system iSybislaw przedstawić jako ogród botaniczny, w którym zgromadzone są różnorodne gatunki roślin. Pełen opis bibliograficzny może więc być tabliczką, która znajduje się przy każdej roślinie w takim ogrodzie. Adnotacje i abstrakty zaś to najważniejsze informacje przekazywane na takich tabliczkach.

\section{Ekscerpowane źródło}

Bibliograficzna baza danych światowego językoznawstwa slawistycznego iSybislaw. (b.d.). Pobrano 21 czerwca 2013, z http://www.isybislaw.ispan.waw.pl

\section{Bibliografia}

Bojar, B. (2002). Stownik encyklopedyczny informacji, języków i systemów informacyjno-wyszukiwawczych. Warszawa: Wydawnictwo Stowarzyszenia Bibliotekarzy Polskich. (Nauka, Dydaktyka, Praktyka; 56).

Drabik, L., Kubiak-Sokół, A., Sobol, E., \& Wiśniakowska, L. (2010). Słownik języka polskiego $P W N$. Warszawa: Wydawnictwo Naukowe PWN.

Grucza, S. (2004). Od lingwistyki tekstu do lingwistyki tekstu specjalistycznego. Warszawa: Uniwersytet Warszawski. Katedra Języków Specjalistycznych.

Woźniak, J. (2002). Jakość w opracowaniu rzeczowym zbiorów bibliotecznych. Biuletyn EBIB, 31(2). Pobrano 21 czerwca 2013, z http://ebib.oss.wroc.pl/2002/31/wozniak.php 


\section{Abstract and annotation as an element of bibliographic description in the iSybislaw database}

\section{Summary}

Abstract (sometimes called summary) of a scientific publication is a brief text that contains keywords. It is one of the elements of a bibliographic description in the bibliographic database iSybislaw - a modern information retrieval system. In the paper definitions of terms such as abstract, annotation and summary along with their constitutive elements are presented. A characteristics of such short texts inserted in the iSybislaw database in the fields Abstract and Abstract 2 is also given. Based on some examples excerpted from the iSybislaw system a typology of short texts, which are elements of the database bibliographic description, is proposed. The material allows to list three kinds of texts that are being used in the iSybislaw database: annotations, abstracts and biographic annotations.

Keywords: abstract; annotation; bibliographic description; database; information retrieval system; iSybislaw; summary

Słowa kluczowe: abstrakt; adnotacja; baza danych; iSybislaw; opis bibliograficzny; streszczenie; system informacyjno-wyszukiwawczy 